\title{
CONVERSION OF PINEAPPLE JUICE WASTE INTO LACTIC ACID IN BATCH AND FED - BATCH FERMENTATION SYSTEMS
}

\author{
Abdullah Mochamad Busairi \\ Department of Chemical Engineering, \\ Faculty of Engineering, University of Diponegoro \\ Jl. Prof. Soedarto, SH, Tembalang, Semarang, Indonesia, Telp/Fax: +62-24-7460058 ; +62-24-76480675 \\ E-mail: abd busairi@yahoo.com
}

\begin{abstract}
Pineapple juice waste contains valuable components, which are mainly sucrose, glucose, and fructose. Recently, lactic acid has been considered to be an important raw material for the production of biodegradable lactide polymer. The fermentation experiments were carried out in a 3 litres fermentor (Biostat B Model) under anaerobic condition with stirring speed of $50 \mathrm{rpm}$, temperature at $40^{\circ} \mathrm{C}$, and $\mathrm{pH}$ of 6.00. Effect of feed concentration on lactic acid production, bacterial growth, substrate utilisation and productivity was studied. The results obtained from fed- batch culture fermentation showed that the maximum lactic acid productivity was $0.44 \mathrm{~g} / \mathrm{L}$.h for feed concentration of $90 \mathrm{~g} / \mathrm{L}$ at 48 hours. Whereas the lactic acid productivity obtained from fed-batch culture was twice and half fold higher than that of batch culture productivity.
\end{abstract}

Keywords: batch and fed-batch culture, lactic acid, pineapple juice waste

\begin{abstract}
Abstrak
Buangan jus nanas mengandung komponen yang berharga terutama sukrosa, glukosa, dan fruktosa. Asam laktat adalah bahan baku yang terbaru dan penting untuk dibuat sebagai polimer laktat yang dapat terdegradasi oleh lingkungan. Percobaan dilakukan pada fermentor 3 liter (Model Biostat B) di bawah kondisi anaerob dengan kecepatan pengadukan $50 \mathrm{rpm}$, temperatur $40^{\circ} \mathrm{C}$, dan $\mathrm{pH} 6,00$. Pengaruh konsentrasi umpan terhadap produksi asam laktat, pertumbuhan mikroba, pengggunaan substrat dan produktivitas telah dipelajari. Hasil yang didapatkan pada fermentasi dengan menggunakan sistem fed-batch menunjukkan bahwa produktivitas asam laktat maksimum adalah 0.44 g/L,jam dengan konsentrasi umpan, $90 \mathrm{~g} / \mathrm{L}$ pada waktu $48 \mathrm{jam}$. Bahkan produktivitas asam laktat yang didapat pada kultur fed-batch lebih tinggi 2,5 kali dari pada proses menggunakan sistem batch.
\end{abstract}

Kata kunci: kultur batch and fed-batch, asam laktat, buangan jus nanas

\section{INTRODUCTION}

Batch culture fermentation is still the most important process operation used in bio-processing industries due to its simplicity which can be carried out without advanced measurement and control. Batch culture becomes less suitable when substrate inhibition on cell growth by product formation occurs (Hammes and Whiley, 1993). Some problems of batch culture fermentation can be overcome by fed batch operation. Fed batch culture is a batch culture, which substrate nutrients are fed continuously or sequentially without the removal of fermentation broth. It is widely used for the production of microbial biomass, ethanol, organic acids, antibiotic, vitamins, enzymes, and other compound (Roukas and Kotzekidou, 1998). The important rationale of fed batch operations are the excess of carbon caused inhibition of cell growth and the excess of carbon or nitrogen caused the catabolite repression (Wang et al, 1986).

Pineapple juice waste contains valuable components, which are mainly sucrose, glucose and fructose (Abdullah and Mat, 1998). Lactic acid was chosen as the desirable product, as it is one of the most important organic acids widely used in the food of industries. Recently, lactic acid has been considered to be an important raw material for the production of biodegradable lactide polymer (Goksungur and Guvenc, 1997). Abdullah and Mat (2005) studied the 
effect of some parameters, such as initial $\mathrm{pH}$, substrate concentration, temperature, and yeast extract concentration on the yield of lactic acid production from pineapple juice waste by employing batch culture. The highest yield and productivity obtained from batch fermentation at $40^{\circ} \mathrm{C}, \mathrm{pH}$ 6.00, sugar concentration of $52.5 \mathrm{~g} / \mathrm{L}$ with $5 \mathrm{~g} / \mathrm{L}$ of yeast extract were $79 \%$ and 0.32 g/L.h, respectively. Pineapple solid waste utilisation for lactic acid production had also been studied, with only 56\% yield and productivity of $0.1 \mathrm{~g} / \mathrm{L} . \mathrm{h}$ were achieved (Abdullah, 2007).

The aim of this investigation was to examine the potential of fed batch culture as fermentation system for lactic acid production from pineapple juice waste.

\section{EXPERIMENTAL METHODS Substrate}

The fermentation media contained pineapple juice waste was obtained from Malaysian Cannery Sdn. Bhd. Before being used as a substrate, the pineapple juice waste was boiled for 5 minute to deactivate the existing enzymes and followed by filtration to remove the solid particles. It was then stored at $-18^{\circ} \mathrm{C}$ for other batches of fermentation as suggested by Lazaro (1989).

\section{Strain}

The microorganism used in this study was Lactobacillus delbrueckii subsp. delbrueckii ATCC 9649 obtained from DSMZ, Germany. The strain was maintained on MRS agar at $4^{\circ} \mathrm{C}$ and transferred to fresh medium every month.

\section{Inoculum Media}

Each fermentation process was initiated by transferring a small amount of biomass to $250 \mathrm{~mL}$ Erlenmeyer flasks containing $50 \mathrm{~mL}$ of liquid MRS medium. Anaerobic condition was prepared by flushing with nitrogen and sealing the flasks with thigh-fitting rubber stopper. The inoculum was constantly shaken in an incubator shaker at $37^{\circ} \mathrm{C}$ and $150 \mathrm{rpm}$ for 24 hours as suggested by Sakamoto and Komagata (1996).

\section{Batch Fermentation}

The batch fermentation was carried out in a 3 litres fermentor (Biostat B Model). The fermentor was equipped with $\mathrm{pH}$, temperature and dissolved oxygen controllers. The fermentor containing $950 \mathrm{~mL}$ of substrate was firstly sterilised at $121^{\circ} \mathrm{C}$ for 15 minutes. Fifty millilitres of inoculum was sterilised separately and added aseptically into the fermentor. Anaerobic system was generated by sparging the fermentor with nitrogen at $6.5 \mathrm{~mL} /$ minute and homogenisation was done by stirring at $50 \mathrm{rpm}$ (Lund et al, 1992). Samples of $10 \mathrm{~mL}$ were withdrawn from the fermentation broth at regular time interval. The microbial cells were separated by centrifugation for dry biomass determination. The supernatant was immediately frozen for further determination of the lactic acid, glucose, fructose, and sucrose concentrations (Mercier and Yerushalmi, 1992).

\section{Fed-batch Fermentation}

The fermentation was performed in a 3 litres stirred fermentor with effective working volume of 2.5 litres. The fermentation was performed in two steps. In the first step, $700 \mathrm{~mL}$ of pineapple juice waste containing $65 \mathrm{~g} / \mathrm{L}$ of sugar was inoculated with 5\% inoculum, while the lactic acid bacteria were grown in a batch culture for 24 hours. In the second step, the production medium containing 65, 90, and $115 \mathrm{~g} / \mathrm{L}$ of sugar was continuously added into the fermentor from it's above at constant rate of $8.5 \mathrm{~mL} / \mathrm{h}$.

\section{Analysis}

The organic acid content in the sample was measured by HPLC (Waters TM 600). A $250 \mathrm{~mm} \times$ $4.6 \mathrm{~mm}$ ID Spherisob Octyl column (Waters) and UV detector (210nm) were used. The eluent used was 0.2 $\mathrm{M}$ phosphoric acid at flow rate of $0.8 \mathrm{~mL}$ per minute and temperature of $25^{\circ} \mathrm{C}$.

The sugar content was also measured by the same apparatus, using a $300 \mathrm{~mm} \times 4 \mathrm{~mm}$ ID $\mu$ Bondapak/Carbohydrate column (Waters) with RI detector. The eluent used was a mixture of acetonitrile : water (80:20) at flow rate of $2 \mathrm{~mL}$ per minute and temperature of $25^{\circ} \mathrm{C}$.

Cell concentration was quantified by constructing a calibration curve of optical density as a function of dry cell weight. The optical density was measured on spectrophotometer Model (UV-1601) at $620 \mathrm{~nm}$. Dry weight determined by centrifugation of fermentation broth at $4000 \mathrm{rpm}$ for 15 minute, washing it twice with distilled water and dried at $103^{\circ} \mathrm{C}$ for 24 hours and followed by weighing (Abdullah, 2007).

\section{RESULTS AND DISCUSSION}

Effect of Feed Concentration on Lactic Acid Production and Bacterial Growth

The feedings were begun at exponential growth rate (24 hour). The effect of the feeding concentration on lactic acid production and bacterial growth were shown in Figure 1.

Figure 1a shows that the lactic acid production increased with the increase of sugar content in the feed. The highest concentration of lactic acid of 59.69 $\mathrm{g} / \mathrm{L}$ was obtained at sugar concentration in the feed of $115 \mathrm{~g} / \mathrm{L}$, and almost similar result was obtained at $57.76 \mathrm{~g} / \mathrm{L}$ lactic acid for substrate feeding containing $90 \mathrm{~g} / \mathrm{L}$ of sugar. The lactic acid yields were $78.83 \%$, $64.17 \%$ and $51.90 \%$ at feeding concentration of 65 g/L, $90 \mathrm{~g} / \mathrm{L}$ and $115 \mathrm{~g} / \mathrm{L}$, respectively. 


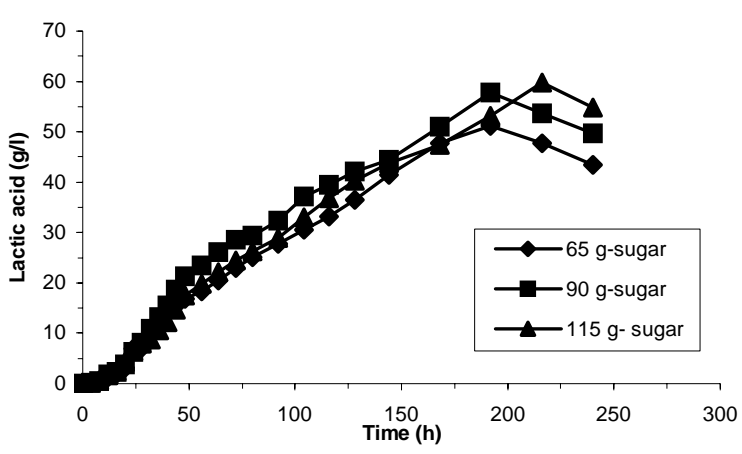

(a)

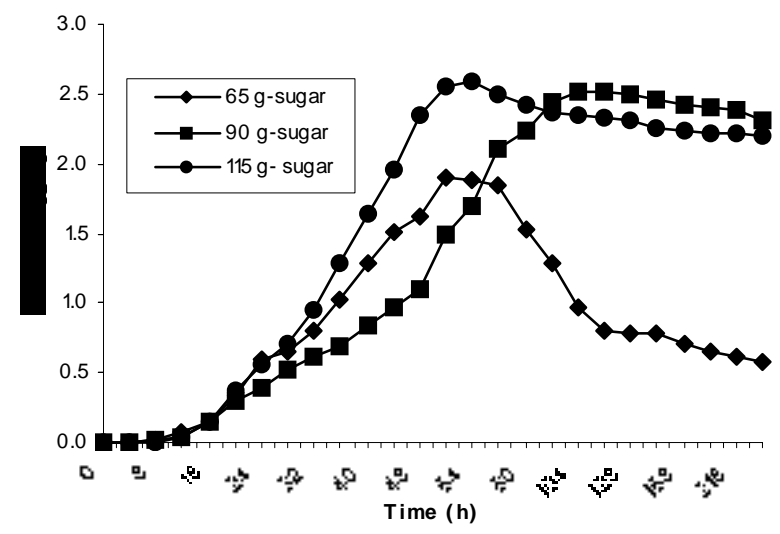

(b)

Figure 1. a) Lactic acid production and b) bacterial growth on pineapple waste juice fermentation using fed batch culture with different of feed concentration.

Experimental conditions: $\mathrm{T}=40^{\circ} \mathrm{C}, \mathrm{pH}=6.0,5 \%$ inoculum and stirring speed $=50 \mathrm{rpm}$.

Figure $1 \mathrm{~b}$ shows that at feed concentration of $90 \mathrm{~g} / \mathrm{L}$ the bacteria growth faster than that of 65 and $115 \mathrm{~g} / \mathrm{L}$, due to inhibition by high sugar concentration in medium. The maximum concentration of biomass obtained at substrate feedings of 90 and $115 \mathrm{~g} / \mathrm{L}$ was obtained similar of $2.5 \mathrm{~g} / \mathrm{L}$. At substrate feeding containing $65 \mathrm{~g} / \mathrm{L}$ of sugar, the maximum biomass concentration was only $2 \mathrm{~g} / \mathrm{L}$. Surprisingly, the bacteria growth at this feeding condition was faster than that at $115 \mathrm{~g} / \mathrm{L}$, even though it then declined gradually after 80 hour. This indicated that at feed concentration of $65 \mathrm{~g} / \mathrm{L}$, the concentration of nutrient in medium was not sufficient to maintain the growth of the cell.

\section{Effect of Feed Concentration on Substrate Utilization}

Figure 2 shows that the concentration of residual sugar decreased in batch fermentation, while it increased during fed-batch culture, except at feeding substrate concentration of $65 \mathrm{~g} / \mathrm{L}$. After 24 hours feeding, the concentration of sugar at feed concentration of $65 \mathrm{~g} / \mathrm{L}$ decreased, but at feed concentration of 95 and 115 sugar $\mathrm{g} / \mathrm{L}$ the sugar concentration increased. This indicated that at feed concentration of $65 \mathrm{~g} / \mathrm{L}$, the rate of lactic acid production much faster than any other substrate feeding rates studied. The sugars seemed to be not completely utilised. This may reflect the complex of nature in pineapple waste juice where the sugar may not be easily metabolised by bacteria.

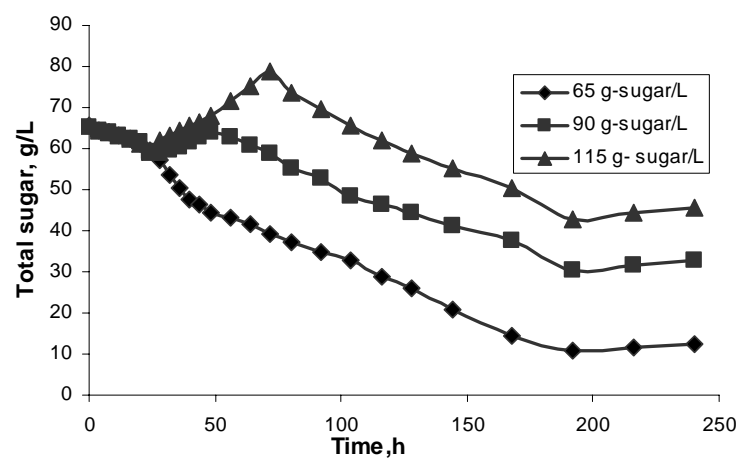

Figure 2. Sugar consumption on lactic acid fermentation of pineapple waste juice using fed batch culture with different of feed concentration.

Experimental conditions: $\mathrm{T}=40^{\circ} \mathrm{C}, \mathrm{pH}=6.0,5 \%$ inoculum and stirring speed $=50 \mathrm{rpm}$.

\section{Effect of Feed Concentration on Lactic Acid Productivity}

Effect of feed concentration on lactic acid productivity can be shown in Figure 3.

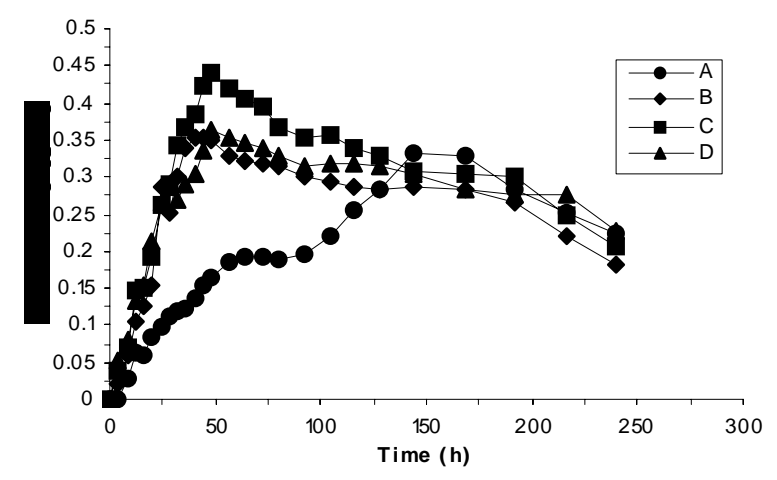

Figure 3. Volumetric productivity on lactic acid fermentation of pineapple waste using batch and fed batch culture. a) batch, b) fed batch $(65 \mathrm{~g} / \mathrm{L})$, c) fed batch $(90 \mathrm{~g} / \mathrm{L})$ and d) fed batch $(115 \mathrm{~g} / \mathrm{L})$.

Experimental conditions: $\mathrm{T}=40^{\circ} \mathrm{C}, \mathrm{pH}=6.0,5 \%$ inoculum and stirring speed $=50 \mathrm{rpm}$.

By increasing the feed concentration (65-90) $\mathrm{g} / \mathrm{L}$, the productivity of lactic acid also increased. However, if sugar concentration in the feed was further increased to $115 \mathrm{~g} / \mathrm{L}$, the productivity decreased due inhibition by excess sugar in the culture media. If the results obtained from 24 hours of fedbatch fermentation were compared to that of batch culture, the lactic acid productivity was twice and half fold higher. The fed-batch culture also generated higher lactic acid concentration, lactic acid yield, lactic acid productivity and biomass concentration. 
Figure 3 also presents the results for the volumetric productivity of lactic acid at different substrate concentration of feedings. The maximum productivity was $0.44 \mathrm{~g} / \mathrm{L}$ obtained from feeding of 90 g/L.h at 48 hour. Roukas and Kotzekidou (1998) obtained lactic acid maximum productivity of $4 \mathrm{~g} / \mathrm{L} \mathrm{h}$ with feeding rate of $97.2 \mathrm{~g} / \mathrm{L}$ at 19 hour. The difference of this finding is due to substrate used in this fermentation. In this work, the substrate contained materials inhibiting the lactic acid production causing lower volumetric productivity.

\section{CONCLUSION}

The maximum productivity of lactic acid production from fed-batch of pineapple juice waste fermentation by Lactobacillus delbrueckii obtained was $0.44 \mathrm{~g} / \mathrm{L}$ with feed concentration of $90 \mathrm{~g} / \mathrm{L} . \mathrm{h}$ at 48 hour. This result was twice and half fold higher than batch fermentation productivity.

\section{REFERENCES}

Abdullah, (2007), Solid and Liquid Pineapple Waste Utilisation for Lactic Acid Fermentation Using Lactobacillus Delbrueckii, J. Reaktor, 11(1), 50-52, ISSN 0852-0798.

Abdullah, M.B and Mat, H.B, (2005), Recycling of Pineapple waste Using Lactobacillus Delbrueckii to Lactic Acid, Proceeding in Second International Seminar on Environmental Chemistry and Toxicology, 73-76, ISSN 1693-0185

Abdullah, M.B and Mat, H.B., (1998), Pencirian Bahan Sisa Nanas Tempatan, Simposium Kimia Analisis ke Sebelas, Universiti Technologi Malaysia.
Goksungur, Y. and Guvenc, U., (1979), Batch and Continuous Production of Lactic acid from Beet Molasses by Lactobacillus Delbrtueckii IFO 3202,J. Chem. Tech. Biotechnology, 69, 399-404.

Hammes, J.M. and Whiley, R.A., (1993), Batch and Fed-Batch Operation, In_Rehm, H.J. and Reed, G., Biotechnology, New York : VHC Weinheim, 143-145.

Lazaro, M.J., (1989), Liquid Chromatographic Determination of Acid and Sugar in Homolactic Cucumbar Fermentation, Journal AOAC, 72(1): pp 5255.

Lund, B., Norddahl, B., and Ahring, B., (1992), Production of Lactic Acid from Whey Using Hydrolysed Whey Protein as Nitrogen Source, Biotechnology Letters, 14 (9): pp 851-856.

Mercier, P. and Yerushalmi, L., (1992), Kinetics of Lactic Acid Fermentation on Glucose and Corn by L. amylophilus, J. Chem Tech. Biotechnology, 55: pp 111 - 121.

Roukas, T. and Kotzekidou, P., (1998), Lactic Acid Production from Deproteinized Whey by Mixed Cultures of Free and Coimmobilized Lactobacillus casei and Lactococcus lactis cell using Fed Batch Culture, Enzyme Microb. Technology, 22(2), 199-204.

Sakamoto, M. and Komagata, K., (1996), Aerobic Growth of An Activities of NADH Oxidize and NADH Peroxides in Lactic Acid Bacteria, $J$. Fermentation and Bioengineering, 29: pp 591 - 602.

Wang, D.I.C., Cooney, C.L., Demain, A.L., Humprey, A.E., and Lilly, M.D., (1986), Fermentation and Enzyme Technology, John Wiley and Sons, New York. 